\title{
Introduction: collaborative public management as an emergent field
}

\author{
Jack Wayne Meek
}

Collaborative public management (CPM) is now a central area of study (O'Leary and Vij 2012) and practice (McKinney and Johnson 2009; Linden 2010; Agranoff 2012) in public administration. As a field of study, its origins can be traced to public management research in intergovernmental relations. Ground-breaking work in the field came from examining intergovernmental networks (Agranoff 1990; Rhodes 1997; Kickert, Klijn and Koppenjan 1997; Agranoff and McGuire 2003, among others). The study of collaborative public management received focused attention examining various models and typologies in networks (Mandell 2001) and in a 2006 symposium edited by Rosemary O'Leary, Catherine Gerard and Lisa Blomgren Bingham (2006). In 2008, Lisa Blomgren Bingham and Rosemary O'Leary collected works from the third Minnowbrook Conference that emphasized Big Ideas in Collaborative Public Management (Bingham and O'Leary 2008). The status of the field and an assessment of where the field is headed was also provided by Rosemary O'Leary and Nidhi Vij (2012).

Collaborative public management has received considerable attention from all over the world since the turn of the century (see Chapter 2 in this volume). The significant growth of the field has made a comprehensive synthesis difficult, if not impossible. However, given the expanded interest, now is an opportune time to examine a variety of ongoing research efforts that represent the broad range of interests in the field and to gain insight into potential future directions, including new areas of study that need attention.

The purpose of this Handbook is to offer a wide range of research in collaborative public management. It is comprised of original chapters from scholars from around the world. This Handbook charts a path of inquiry that embraces related fields of study that have received considerable attention in other handbooks, such as those on governance (Massey and Johnston 2015; Ansell and Torfing 2016; Heinelt 2018), as well as integrative treatises on governance networks (Klijn and Koppenjan 2016; Koliba, Meek, Zia and Mills 2018). Finding the connection among the many areas of examination in collaborative governance is one feature of this volume. As such, this volume provides a selection of original scholarship contributing to this emergence of collaborative governance research and seeks to address common interests among these works in the public sphere around the different arenas of collaborative governance, the practice of practice, and the limits and possibilities of collaborative governance. Collaborative processes can be found within organizations, among organizations and across the various jurisdictions and sectors of society, including our global arenas. 


\section{CONTRIBUTING FEATURES OF THE FIELD}

Interest in and the study of collaborative public management has spawned many areas of inquiry. Often, we find the field of collaborative management research catching up with the quickly evolving practices of public officials seeking associations and collaborators to address problems they cannot solve on their own initiatives. Collaborative public management represents a form of governance where "the process of facilitating and operating in multi-organizational arrangements to solve problems that cannot be solved, or solved easily, by single organizations" (Agranoff and McGuire 2003, p. 4). The field of collaborative public management is characterized by a broad range of study foci. Emerson, Nabatchi and Balogh developed an integrative framework around current research in the field (2012). Ansell and Torfing (2016) assessed and summarized the areas of study by distinguishing concepts, theoretical modes and forms of governance.

There are important scholarly efforts that seek to distinguish between collaborative public management and collaborative governance (Kapucu, Yuldashev and Bakiev 2009; O'Leary and Vij 2012). These distinctions are made in order to strengthen theoretical development and provide analytic clarity. For example, one might argue that collaboration within bureaucracies (among departments) can be differentiated from collaboration with citizens (civic engagement and co-production) or collaboration with private enterprises (public-private partnerships) or collaboration across jurisdictions (horizontally and vertically). Indeed, each of these forms of collaboration contain dynamics that are relevant to examine from a narrowed frame of reference so as to draw out significant patterns for explanation. The approach of this volume is to examine patterns across these kinds of collaborative experiences so as to improve our understanding of collaborative public administration.

For the purposes of this Handbook, the frame of reference for addressing collaborative public management is to take a more integrative view of the common features of the approaches outlined above, especially those that address the collaborative nature of the interaction. At some point, it may be useful for research reasons to distinguish collaboration in networks compared to other kinds of engagement settings, but this is not the approach for contribution outlined here. Indeed, at this point of time it may be important to embrace the collaborative nature that is found in public management, citizen engagement, governance networks and cross-sector relations.

Below is a summary of important areas of study in collaborative public management that have informed this field of study:

Networks - The network approach to the study of public management was shaped by the work of Kickert, Klijn and Koppenjan in their work on managing complex networks (1997). The study of governance networks has evolved to address the conditions of network design and implementation. The challenges of governance networks - performance and accountability - has received considerable attention. Defining "Network" - O'Toole (1997) offered the following:

Networks are structures of interdependence involving multiple organizations or parts thereof, where one unit is not merely the formal subordinate of the others in some larger hierarchical arrangement. Networks exhibit some structural stability but extend beyond formally established linkages and policy-legitimated ties.... The institutional glue congealing networked ties may include authority bond, exchange relations, and coalitions based on common interest, all within a single multi-unit structure. (O'Toole 1997, p. 45) 
Milward and Provan (2006) identified the essential tasks in the management of networks and Agranoff examined leadership and management (Agranoff 2006, 2007; Crosby and Bryson 2007; O'Leary and Bingham 2009) of networks. Refinement of the management focus was established in the work of Robert Agranoff (2012). Some authors use the term "network" as a cornerstone to identify different types: policy networks, collaborative networks and governance networks (Isett, Mergel, LeRoux, Mischen and Rethemeyer 2011). Some authors have focused on the term "network" as the central feature to be examined in approaching governance (Keast, Mandell and Agranoff 2014). Governance networks includes those relationships among multiple actors who are networked and where public agencies oversee private organizations or who contract private organizations who provide public services (Provan and Kenis 2007). Goldsmith and Eggers (2004) developed a design approach in the building of governance networks. Often, networks are formed to address extreme events that challenge many jurisdictions at the same time (Comfort, Boin and Demchak 2010). Indeed, some of the maturing literature on collaboration in public management can be found in the examination of emergency networks (see Chapter 9 in this volume). There appear variations in the use of the term governance networks, including the use of the term public management networks (see Chapter 2 of this volume) and network governance (Keast 2016; Kapucu and $\mathrm{Hu} 2020$ ).

Civic engagement - CPM embraces the area of civic engagement and includes approaches to and the practice of including citizens in the creation, design and implementation of public services (O’Leary, Gerard and Bingham 2006; Cooper, Bryer and Meek 2006). The work of Robert Putnam (2000) inspired a number of efforts to examine how citizens can be engaged in civic organization and in government as a kind of "new governance" (Bingham, Nabatchi and O'Leary 2005). Collaboration as Civic Engagement was viewed broadly by Macedo et al. (2005) and defined civic engagement: "any activity, individual or collective, devoted to influencing the collective life of the polity" $(2005$, p. 6). A significant number of research efforts drew upon Shery Arnstein's (1969) "ladder of civic participation" in order to examine paths toward citizen engagement with governmental policy and service design. The many interests in this area of study included the co-production of public services by citizens working with government (Bovaird 2007) and the focus on empowering citizens in driving policy design and implementation (Fung 2009; see also Chapters 14 and 15 of this volume). Innes and Booher (1999) advanced the study of civic engagement and participation by examining "consensus building" processes in collaborative settings. Their research led them to advance the concept of "collaborative rationality" in how stakeholders can enhance common interests and develop common agendas for collective action through building significant relational connections through meaningful processes that establish significant levels of institutionalized patterns of interaction (Innes and Booher 2010, 2016; Innes 2016).

Governance - Another frame of reference in the field of collaborative public administration is governance, where the study is focused on the "interactive processes through which society and the economy are steered toward collaboratively negotiated objectives" (Ansell and Torfing 2016, p. 4). Governance can take on various forms, including network, collaborative, multi-level, transnational, supranational, democratic and adaptive. Collaborative Governance - The often-cited work of Ansell and Gash set the standard for framing the concept of collaborative governance, "a governing arrangement where one or more public agencies directly engage non-state stakeholders in a collective decision-making process that is formal, consensus-oriented, and deliberative and that aims to make or implement public policy or manage public programs or assets" (Ansell and Gash 2008, p. 544). Scott and Thomas (2017) 
conceptualized collaborative governance as a toolbox for public managers. Collaborative Governance Regimes (types and forms) advanced the understanding of collaborative governance in that various types of collaborative governance (regimes) can be identified and that the concept of regime recognizes the broader array of actors that can be involved in issue-area management over time (Emerson and Nabatchi 2015). These authors extend their work in this volume by differentiating implementation nuances that are characteristic of different kinds of collaborative governance regimes (see Chapter 24 in this volume).

Cross-sector Collaboration - Another area of study is in cross-sector collaboration where government strategies in working with private and non-profit agencies have emerged (Bryson, Crosby and Stone 2006; Simo and Bies 2007). Bryson, Crosby and Stone define cross-sector collaboration as "linking or sharing of information, resources, activities, and capabilities by organizations in two or more sectors to achieve jointly an outcome that could not be achieved by organizations in on sector separately" (2006, p. 44). This area of emphasis in collaborative public management would include a wide range of partnerships, such as public-private partnerships and public non-profit partnerships. In continuous work of Bryson, Crosby and Stone (2015) we can find integrative work that summarizes different frameworks of cross-sector collaboration and collaborative governance to assess fundamental concerns with structures and processes that influence collaborative outcomes and the achievement of public value (Bryson, Crosby and Bloomberg 2014). Chapter 7 of this volume examines the challenge of building collaborative public-private partnerships.

Complex Systems - Another area of interest is the research examining governance in complex settings. This approach seeks to examine underlying patterns of emergent properties in settings that are characterized when there are many actors interacting with no central authority. Early work in this area by Douglas Kiel $(1989,1994)$ emphasized the necessity of governmental change and innovation in dynamic settings. Kickert, Klijn and Koppenjan (1997) relied on complexity as a condition underlying governmental efforts in collaboration. This approach was also embraced by research in governance (Weber 2005; Bovaird 2008; Teisman and Klijn 2008; Teisman, van Buuren and Gerrits 2009). Recent research seeks to identify different kinds of complexity where governments operate (Lubell 2013; Klijn and Koppenjan 2016). The complexities of public policy design and implementation involves risk taking on the part of participants (Comfort 2019) and central to successful collaborative efforts will be seeking stakeholder consensus in forming collective action to achieve resilient outcomes (Innes and Booher 2010; see also Chapters 5 and 8 of this volume).

The five contributing areas in the examination of collaborative public management outlined above is one way of framing the field. As the reader shall see in the review of the chapters that follow, there are overlapping themes and subjects among the areas of examination. Research on cross-cutting research and methodologies in the field can be found in the work of Keast, Koliba and Voets (2019). Figure I.1 offers an illustration of the contributing areas of examination in collaborative public management.

\section{Understanding the Uniqueness of Collaborative Public Management}

With the study of collaborative public administration, the field of public administration may have found one of its central cornerstones that distinguishes the field from other areas of study. In CPM, scholars are seeking to embrace the emergence of current practices of public 


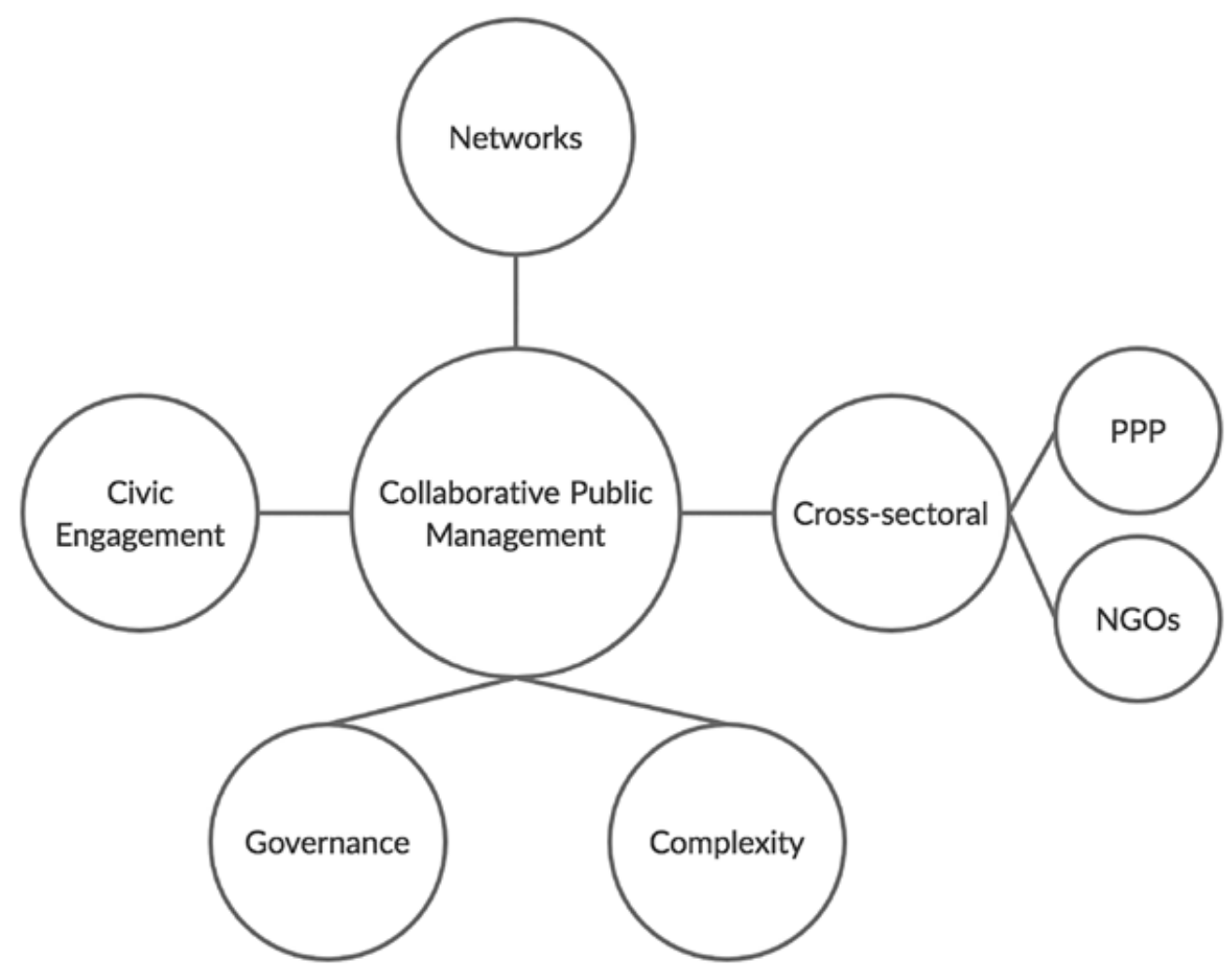

Figure I.1 Contributing areas of study in collaborative public management

administration and their implications. In addition, the foundations of the field may be usefully expressed in its collaborative nature. In the words of H.G. Frederickson (1999):

It is public administration that is responding to structural and contextual dynamics - the problems of jurisdictions and systems disorder, unpredictability and instability. It is no surprise therefore, that theories which explain behavior under such circumstances come from modern public administration. These theories have much less to do with markets, competition, and individual choice, and more to do with theory of institutions and forms of natural and voluntary cooperation ... public administration is naturally interjurisdictional, networked, and comfortable in the new world of governance. (Frederickson 1999, p. 710)

With the advancement of cross-boundary challenges that the international, nation-state and its sub-national components (states, regions, provinces, cities and towns) need to address, the traditional jurisdictions systems we have created to respond to these challenges may very well be "disarticulated" (Frederickson 1999). The emergence of collaborative public management and the concomitant rise of governance networks is a practical response to cross-jurisdictional problems. Indeed, at the turn of this century, it was Donald Kettl (2002) who identified the transformation underway in governing toward governance. Some have referred to this transformation as a new public governance (Osborne 2010). As a field of inquiry, we have 


\section{Handbook of collaborative public management}

responded to the call of Laurence O'Toole (1997) and continually sought to examine the collaborative networks in public administration that are characteristic of this transformation.

\section{Questions of Interest in Collaborative Public Management}

This Handbook is a collection of new research and integrative reviews of the literature that address the central questions that emerge from the ongoing formation of collaborative public management approaches in the public sphere: What challenges and issues drive the need for collaborative efforts? What sectors can and should be involved in collaborative public management service designs? What are the reasons to collaborate? What risks are involved in forming collaborative agreements? Who is involved in the collaboration? How does the diversity of actors in collaboration influence policy and implementation? What form does collaboration take? What is the role of leadership in creating opportunities for collaboration? These and related questions permeate the research and practice of collaborative public management (see Figure I.2).

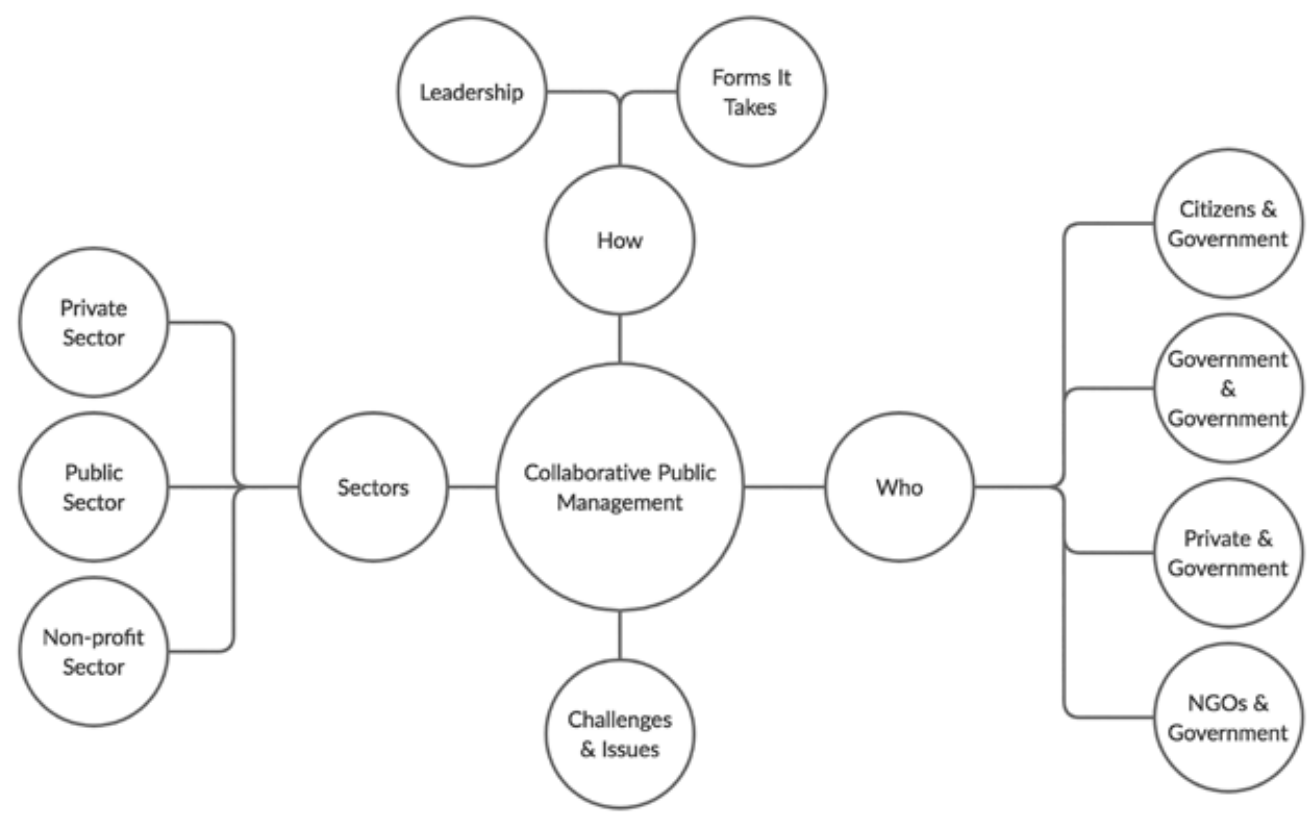

Figure I.2 Questions of research interest in collaborative public management

In addressing these central questions, the chapters collected here draw the different contributing areas of collaborative public management: networks, civic engagement governance, cross-sector collaboration, and complex systems. 


\section{ORGANIZATION OF THE HANDBOOK}

\section{Finding the Nexus of Collaboration in Public Management Research}

The structure of the book is organized into four areas: practices and patterns, arenas, limits, and the possibilities of collaborative public management. These areas of focus were chosen so as to move analysis to areas that work across boundaries. Practices and patterns are those areas that make collaboration work: negotiation and professional and communities of practice within networks. Who should be included in collaborations and what level of diversity should be considered? How do stakeholders in a shared governance environment prioritize goals among stakeholders? Arenas of collaborative public management include public-private partnerships, commons management (freshwater, environment, space, oceans), emergency management. Arenas of collaborative public management include local governmental jurisdictions that seek mutual coordination of service design and delivery. These designs can also embrace citizen involvement in the financial decisions of local government services and the cross-jurisdictional agreements to solve service designs that individual jurisdictions cannot effectively produce individually. Limits of collaboration refers to areas of study that reveal either where collaboration is feasible or effective (Provan and Kenis 2007; see Chapter 18 in this volume) and where coordination is not possible due to rationally determined interests (O'Toole 1995; see also Chapters 17 and 19 in this volume). The possibilities of collaborative public management refer to areas of collaboration identified by scholars that establish new paths of collaboration or ways collaboration can overcome limits to collaboration and establish ways these collaborations can be democratically responsive (Sørensen and Torfing 2007, 2009). Chapter 26 of this volume addresses the necessity of collaboration given societal interconnectedness and the vision to connected networks of collaboration globally. What follows is a brief summary of contributions organized around the themes outlined above.

\section{PRACTICES AND PATTERNS OF COLLABORATIVE PUBLIC MANAGEMENT}

This section of the Handbook focuses on the fundamental cornerstones of collaboration in public management: the practices and patterns of interaction that allow for the operations of administrative coordination and interaction.

\section{What is Collaboration and What Do We Know About Collaboration?}

The first two chapters of this section seek to clarify the definition and foundations of collaborative public management. In the first chapter, Margaret Stout and Robyn Keast seek to clarify the meaning of collaboration. The authors offer a typology, drawn from an interdisciplinary frame of reference, that differentiates collaboration from other forms of connectivity. The authors draw on these distinctions to assist future research and practice in collaborative public management.

The second chapter, by Göktuğ Morçöl, Eunsil Yoo, Shahinshah Faisal Azim, and Aravind Menon, reviews and examines the academic literature on collaborative governance networks. The authors reveal the extensive growth in the number of publications, the spread of published 
interest both across areas of study, and the expansion of interest in the field across countries. The authors also comment on the nature of inquiry on collaborative governance networks to date to be mostly theoretical with limited empirical research employed.

\section{What are the Practices of Collaborative Public Management?}

The next four chapters of this section are devoted to understanding what makes collaborative public management possible. Chapter 3, by Elise Boruvka and Lisa Blomgren Amsler, focuses on the central role of negotiation as an essential skill in the formation of collaborative responses to complex issues. Negotiation leading to collaboration is essential because it is recognized that individual organizations cannot solve complex issues on their own. The authors examine the role of interest-based negotiation in developing and maintaining cross-sectoral collaborations among public, private and non-profit organizations. The critical skills of communication and conflict management also contribute to successful negotiations in recognizing unique and common interests among the network stakeholders.

Chapter 4, by Christopher Koliba, emphasizes that communities of practice $(\mathrm{CoP})$ - groups of practitioners operate as "social learning systems" to solve problems - carry out the essential management functions of a collection of agencies pursuing collective action. As illustrated in two case studies, interpersonal relationships play a significant role in these communities of practice and shape the nature of coordination and collective action.

In Chapter 5, Lasse Gerrits and Robin Chang examine the important question of who should be included in the collaborative effort? Specifically, the authors examine how diversity in collaborative processes influences goal attainment. Two case studies - from Switzerland and Germany - serve as an avenue to examine how diversity in participants influences problem definition, solution creation and supported outcomes in collaborative efforts. The authors argue that intentional diversity will lead to significant reciprocal processes that enable more sustainable outcomes.

Chapter 6, by Asim Zia and Christopher Koliba, examines the practice of prioritization of transportation infrastructure projects in highly diverse and state regional transportation agency settings. Drawing on this case study, the authors examine project transportation prioritization between "system preservation" and "environmentally oriented" criteria. Findings from primary and secondary data reveal a "system preservation" funding emphasis that needs reassessment among transportation actors.

\section{ARENAS OF COLLABORATIVE PUBLIC MANAGEMENT}

This second section of the Handbook offers exemplary research on the various arenas of collaborative public management: public-private partnerships, freshwater governance, emergency management, local governmental service agreements, environmental governance, and civic engagement.

\section{How Can We Improve Collaborative Public Management in Different Arenas?}

In the first chapter of this section, Chapter 7, Erik Hans Klijn, Joop Koppenjan, and Rianne Warsen examine extensive research on public-private partnership (PPP) collaboration to offer 
an integrative view of what determines successful collaboration. The authors argue that a mix of contractual arrangements are needed for successful collaborations.

Embracing the complexities of environmental governance, in Chapter 8 Elizabeth Eppel and Jackie Dingfelder examine collaborative approaches to the management of scarce freshwater resources. The complexities of multiple jurisdictions and interests frame the necessity for collaborative governance among multiple and diverse stakeholders. Drawing on three case studies in the United Sates and New Zealand, the authors identify the promise of collaborative governance in developing solutions to freshwater governance. The authors also warn of the challenge presented by traditional authorities if not embraced as part of these collaborative networks.

Jenna Tyler and Naim Kapucu, in Chapter 9, provide an assessment of emergency management, one of the most active sectors seeking to build capacity to address numerous public hazards. In this examination, the authors observe that while this subject has attracted sizeable research interests, the field lacks an integrated framework for assessing the effectiveness of emergency management networks. The authors address the gap by offering an integrative framework for such an assessment and the implications of the framework for those operating in the field. Siobhan McQuaid, Mary Lee Rhodes, and Aitziber Egusquiza Ortega, in Chapter 10, address how to approach climate change initiatives. As identified by both the United Nations (UN) and the European Community (EC), nature-based solutions have received priority in contributing to meeting UN Sustainability Goals. To implement the goals set forth by the UN SDGs, the authors offer a new model of governance - the Key Actors Governance Framework - that holds potential to integrate nature-based solutions with governance requisites.

\section{What Determines Collaborative Service Agreements in Local Government Arenas?}

The next two chapters seek to examine the motivation of local administrators in participating in collaborative service initiatives either vertically or horizontally. In Chapter 11, by Jun Li, José Sánchez, Jered B. Carr, and Michael D. Siciliano, the authors seek to understand who is involved in local intergovernmental agreements, why they are involved and how the agreements are implemented. Drawing upon 500 agreements in Iowa, the authors find that service contracts predominate the kind of local agreements (versus other forms of agreements) formed, that motivation to develop agreements is to provide access to citizens and the institutional forms of agreements reveal moderate levels of institutional integration.

Chapter 12, by Evan Walter and Kurt Thurmaier, also examines the motivation to participate in interlocal agreements and focuses on the risks of forming such agreements by municipal managers. The authors study Illinois municipal managers and develop an experimental design on contracting and investment opportunities testing how risk influences decisions on entering into agreements in service delivery. The predominant finding is that positively framed gains influence municipal managers toward service agreements.

\section{How can Local Governments Engage Citizens in Policy Design and in Local Government Arenas?}

The final three chapters of this section on the arenas of collaboration focus on civil society and how governments engage citizens in the design and implementation of public policy and service. Chapter 13, by Marcia L. Godwin, examines the role of local community engagement 
efforts in public budgeting. While traditional participatory budgeting (PB) approaches still continue to offer benefits in facilitation relations among jurisdictional stakeholders, new forms of technology-driven approaches also hold potential in facilitating collaboration. But with these advances, the author comments that collaborative efforts need to keep pace with the change priorities highlighted in recent events.

In Chapter 14, Sofia Prysmakova-Rivera identifies central features of civic engagement in collaborative public management and the challenges related to current practice. To overcome these challenges, new principles of "democratic citizen engagement" are offered to enhance the power with citizens in improving performance of collaborative networks.

Thomas Andrew Bryer, in Chapter 15, is concerned with how current forms of collaborative governance perpetuate existing societal inequities. The author then offers a different orientation to collaborative governance that embraces citizen deliberation. The author refers to this orientation as "collaborative empowerment" that seeks to treat citizens in the process as co-contributors and learners in the process rather than recipients and passive participants.

\section{THE LIMITS OF COLLABORATIVE PUBLIC MANAGEMENT}

This section of the Handbook offers four chapters that provide insight into the limitations of collaborative public management (McGuire and Agranoff 2011). The authors of this section examine where limitations can be identified and whether these limitations can or should be addressed. Chapter 16, by Kathy Quick, examines the complexities of intergovernmental collaboration with tribal governments in the United States. From the foundation of respect for tribal sovereignty and native people's rights, the author examines the issue of roadway safety in reservations that is a result of antagonistic relations among governments. The author includes examples of constructive intergovernmental collaboration that offer guidance to improve respect among stakeholders that can lead to meaningful collaboration around roadway safety in reservations as well as other arenas of intergovernmental coordination.

The fragmentation of authority in intra-organizational settings is the focus of Heewon Lee in Chapter 17. Authority fragmentation among governmental agencies inhibits their ability to coordinate efforts. These collective action dilemmas are examined through the framework of Institutional Collective Action to identify areas needing attention to overcome the challenges of functional collective action among governmental stakeholders.

In Chapter 18 Frank Naert offers welfare economics as a way to understand how governments can coordinate efforts to implement the United Nations Sustainable Development Goals (SDGs). The author argues that collaborative governance cannot solve equity issues but can be a useful tool in supplying global public goods. Identifying benchmarks, through the contribution of welfare economics, will offer assistance in regard to identifying levels of governance best suited for achieving SDGs.

Developing regionwide planning in fragmented regional governance settings is the focus of Soomi Lee in Chapter 19. Fragmented settings represent tensions in local regions inhibiting voluntary collaboration. To overcome these tensions, state action that preserves local autonomy offers promise. The study examines an illustration of such action - the Twin Cities metropolitan area - as a potential exemplar of state action overcoming regional fragmentation. 


\section{ADVANCING COLLABORATIVE PUBLIC MANAGEMENT PERFORMANCE}

In this final section, authors examine ways to advance performance in collaborative public management. These seven chapters focus on the possibilities for collaborative public management. The initial chapter of this section examines how the use of science can inform the quality of collaborative initiatives. Tomas M. Koontz and Craig W. Thomas, in Chapter 20, review what is known about how scientific information is shared in various collaborative partnerships. In this examination, the authors compare how science is shared in collaborative partnerships compared to the use of science by public agencies. The authors offer this comparison to assess the barriers and bridges that can improve the use of scientific information across various forms of collaboration.

In Chapter 21 Olivier Berthod and Jörg Sydow seek to understand the reliability of interorganizational collaboration. This work examines research on reliability as central to organizational effectiveness. The examination includes the use of both formal and informal practices that influences reliability in interorganizational settings.

Carmine Bianchi, in Chapter 22, offers a way to assess sustainable community outcomes through an integrated Dynamic Performance Management and Governance framework. Drawing on case studies, the approach outlined is based on ideas developed in Dynamic Performance where emphasis is placed on outcome-based performance management and continuous feedback. The implication of this approach is to enhance leadership that relies on process and accountability orientations that improve interorganizational collaboration.

Robert Agranoff, one of the leading scholars in the field of collaborative public management, offered this contribution before his passing in the fall of 2019. In this work, Chapter 23, Agranoff elaborates on his ideas for continuous improvements in collaborative efforts. Agranoff seeks to raise our level of understanding in regard to collaborative efforts - that there is no single measure to assess performance in organizations. Through illustrations, Agranoff demonstrates that we are learners in these multi-organizational settings and that attention needs to focus more on how we embrace public understanding of these collaborative initiatives.

Tina Nabatchi and Kirk Emerson expand on the concept of "collaborative governance regimes" as a way to examine implementation in collaborative arrangements. In Chapter 24 , the authors point out the dynamic environments that call upon multi-actor authorities to develop collaborative actions. The resultant implementation challenges are best viewed through understanding the kind of governance regime that is operating and how the regime is oriented. Based on the Strategic Action Field Framework, the authors develop a typology of governance regimes to assess collaborative performance.

Effective performance of collaborative governance arrangements must be understood in terms of the context they operate. In Chapter 25, Christopher Ansell, Eva Sørensen, and Jacob Torfing develop a framework of social embedding of collaborative governance that match various contexts. Implications for those who design and implement collaborative governance arrangements is offered.

In the final chapter of this section, Chapter 26, Louise K. Comfort draws on the ongoing global challenge represented by the coronavirus pandemic (COVID-19) to assess the functioning of collaborative governance. This assessment points to broadening our understanding of how collaborative efforts operate beyond stable environments. To do so, Comfort offers an "action framework" for operational networks that will allow for adaptation to dynamic 
environments. Comfort uses the first five months of the California response to the coronavirus pandemic to illustrate the operation of the action framework and calls for the necessity of building governance networks that are able to adapt to rapidly changing environments.

\section{THE EMERGENCE OF COLLABORATIVE PUBLIC MANAGEMENT}

From the field of complexity theory, emergence refers to a process of interaction among a variety of actors that is constantly evolving and adapting to its environment (Cilliers 2000). The interaction of ideas and research in the related areas of networks, civic engagement, governance, cross-sector collaboration and complex systems have contributed to an emergent field of collaborative public management. To interpret this emergence, it is important to understand how each area contributes to collaborative public management and understand the larger view of the entire field as a whole (Bar-Yam 2004). Clearly, these areas of examination have much in common, including a focus on how organizations can collaborate: how organizations (public, private, non-profits) or citizens form public management networks to resolve complex issues and achieve mutually beneficial results. In an applied interpretation, any collaboration's emergent process is evolving and will have higher priority to participant organizations' central mission (O'Leary and Vij 2012). As we examine different areas of study in the field of collaborative public management, we also need to reflect on the field as a whole and the emergence it reflects.

The research of this Handbook is organized into four components or common themes across the areas of interest collaborative public management: practices of collaboration, arenas of collaboration, the limits of collaboration and the possibilities of collaboration. There is much to explore in these chapters. The careful reader will benefit greatly from the rich traditions each of the authors represent and the literature that informs their research. As a result, the volume offers a rich source of research and reference. Finally, this Handbook hopes to inspire new ideas for research in this significant and meaningful area of study: collaborative public management.

\section{REFERENCES}

Agranoff, R. (1990). Frameworks for comparative analysis of intergovernmental relations. Occasional Paper \#26, School for Public and Environmental Affairs, Indiana University, August.

Agranoff, R., \& McGuire, M. (2003). Collaborative Public Management: New Strategies For Local Governments. Washington, DC: Georgetown University Press.

Agranoff, R. (2006). Inside collaborative networks: Ten lessons for public managers. Public Administration Review, 66(SI), 56-65.

Agranoff, R. (2007). Managing Within Networks: Adding Value to Public Organizations. Washington, DC: Georgetown University Press.

Agranoff, R. (2012). Collaborating to Manage: A Primer for the Public Sector. Washington, DC: Georgetown University Press.

Ansell, C., \& Gash, A. (2008). Collaborative governance in theory and practice. Journal of Public Administration Research and Theory, 18(4), 543-571.

Ansell, C., \& Torfing, J. (Eds.) (2016). Handbook on Theories of Governance. Cheltenham, UK and Northampton, MA, USA: Edward Elgar Publishing.

Arnstein, S. (1969). A ladder of citizen particpation. Journal of the American Planning Association, 35(4), 216-224. 
Bar-Yam, Y. (2004). Making Things Work: Solving Complext Problems in a Complex World. Knowledge Press, online at www.knowledgetoday.org or www.necsessi.org.

Bingham, L.B., Nabatchi, T., \& O'Leary, R. (2005). The new governance: Practices and processes for stakeholder and citizen participation in the work of government. Public Administration Review, 65(5), 547-558.

Bingham, L.B., \& O’Leary, R. (Eds.) (2008). Big Ideas in Collaborative Public Management. Armonk, NY: M.E. Sharpe.

Bovaird, T. (2007). Beyond engagement and participation: User and community coproduction of public services. Public Administration Review, 5, 846-860.

Bovaird, T. (2008). Emergent strategic management and planning mechanisms in complex adaptive systems. Public Management Review, 10, 316-340.

Bryson, J.M., Crosby, B.C., \& Stone, M. (2006). The design and implementation of cross-sector collaborations: Propositions from the literature. Public Administration Review, 66(s1), 44-55.

Bryson, J.M., Crosby, B.C., \& Bloomberg, L. (2014). Public value governance: Moving beyond traditional public administration and the new public management. Public Administration Review, 74(4), 445-456.

Bryson, J.M., Crosby, B.C., \& Stone, M. (2015). Designing and implementing cross-sector collaboration: Needed and challenging. Public Administration Review, 75(5), 647-663.

Cilliers, P. (2000). What can we learn from a theory of complexity? Emergence: Complexity and Organization. Edition 1, March 31, 2000.

Comfort, L.K., Boin, A., \& Demchak, C.C. (2010). Designing Resilience: Preparing for Extreme Events. Pittsburgh, PA: University of Pittsburgh Press.

Comfort, L.K. (2019). The Dynamics of Risk: Changing Technologies and Collective Action in Seismic Events. Princeton, NJ: Princeton University Press.

Cooper, T.L., Bryer, T., \& Meek, J. (2006). Citizen-centered collaborative public management. Public Administration Review, 66, 76-88.

Crosby, B.C., \& Bryson, J.M. (2007). A leadership framework for cross-sector collaboration. Public Management Review, 7(2), 177-201.

Emerson, K., Nabatchi, T., \& Balogh, S. (2012). An integrative framework for collaborative governance. Journal of Public Administration Research and Theory, 22(1), 1-29.

Emerson, K., \& Nabatchi, T. (2015). Collaborative Governance Regimes. Washington, DC: Georgetown University Press.

Frederickson, H.G. (1999). The repositioning of American public administration. PS: Political Science and Politics, 32(4), 701-711.

Fung, A. (2009). Empowered Participation: Reinventing Urban Democracy. Princeton, NJ: Princeton University Press.

Goldsmith, S., \& Eggers, W.D. (2004). Governing by Network: The New Shape of the Public Sector. Washington, DC: Brookings Institution Press.

Heinelt, H. (Ed.) (2018). Handbook on Participatory Governance. Cheltenham, UK and Northampton, MA, USA: Edward Elgar Publishing.

Innes, J.E., \& Booher, D.E. (1999). Consensus building and complex adaptive systems: A framework for evaluating collaborative planning. Journal of the American Planning Association, 65(4), 412-423. https://doi.org/10.1080/01944369908976071

Innes, J.E., \& Booher, D.E. (2010). Planning with Complexity: An Introduction to Collaborative Rationality for Public Policy. London: Routledge.

Innes, J.E. (2016). Viewpoint Collaborative rationality for planning practice. Town Planning Review, 87(1), 1-4. https://doi.org/10.3828/tpr.2016.1

Innes, J.E., \& Booher, D.E. (2016). Collaborative rationality as a strategy for working with wicked problems. Landscape and Urban Planning, 154, 8-10, https://doi.org/10.1016/j.landurbplan.2016.03.016

Isett, K.R., Mergel, I.A., LeRoux, K., Mischen, P.A., \& Rethemeyer, R.K. (2011). Networks in public administration scholarship: Understanding where we are and where we need to go. Journal of Public Administration Research and Theory, 21(1), 157-173.

Kapucu, N., Yuldashev, F., \& Bakiev, E. (2009). Collaborative public management and collaborative governance: Conceptual similarities and differences. European Journal of Economic and Political Studies, 2, 39-60. 
Kapucu, N., \& Hu, Q. (2020). Network Governance: Theories, Concepts, and Applications. New York: Routledge.

Keast, R.L., Mandell, M.P., \& Agranoff, R. (2014). Network Theory in the Public Sector: Building New Theoretical Frameworks. New York: Routledge.

Keast, R.L. (2016). Network governance. In C. Ansell \& J. Torfing (Eds.), Handbook on Theories of Governance (pp. 442-453). Cheltenham, UK and Northampton, MA, USA: Edward Elgar Publishing.

Keast, R.L., Koliba, C., \& Voets, J. (2019). Cross cutting themes and opportunities for network and collaboration research. In R.L. Keast, C. Koliba, \& J. Voets (Eds.), Networks and Collaboration in the Public Sector: Essential Research Approaches, Methodologies and Analytical Tools (Chapter 14, pp. 256-274). New York: Routledge.

Kettl, D.F. (2002). The Transformation of Governance: Public Administration for Twenty-First-Century America. Baltimore, MD: The Johns Hopkins University Press.

Kickert, W.J.M., Klijn, E-H., \& Koppenjan, J.F.M. (Eds.) (1997). Managing Complex Networks: Strategies for the Public Sector. London: Sage.

Kiel, L.D. (1989). Nonequilibrium theory and its implications for public administration. Public Administration Review, 49(6), 544-551.

Kiel, L.D. (1994). Managing Chaos and Complexity in Government: A New Paradigm for Managing Change, Innovation and Organizational Renewal. San Francisco, CA: Jossey-Bass.

Klijn, E-H., \& Koppenjan, J.F.M. (2016). Governance Networks in the Public Sector. London: Routledge.

Koliba, C., Meek, J.W., Zia, A., \& Mills, R.W. (2018). Governance Networks in Public Administration and Policy (2nd edn). New York: Routledge.

Linden, R.M. (2010). Leading across Boundaries: Creating Collaborative Agencies in a Networked World. San Francisco, CA: Jossey-Bass.

Lubell, M. (2013). The governing of institutional complexity: The ecology of games framework. Policy Studies Journal, 41(3), 537-599.

Macedo, S., Alex-Assensoh, Y., Berry, J.M., Brintnall, M., Campbell, D.E., Fraga, L.R., Fung, A., Galston, W.A., Karpowitz, C.F., Levi, M., Levinson, M., Lipsitz, K., Niemi, R.G., Putnam, R.D., Rahn, W.M., Reich, R., Rodgers, R.R., Swanstrom, T., \& Cramer Walsh, K. (2005). Democracy at Risk: How Political Choices Undermine Citizen Participation, and What We Can Do About It. Washington, DC: Brookings Institution Press.

Mandell, M.P. (Ed.) (2001). Getting Results Through Collaboration: Networks and Network Structures for Public Policy and Management. Westport, CT: Quorum Books.

Massey, A., \& Johnston, K. (2015). The International Handbook of Public Administration and Governance. Cheltenham, UK and Northampton, MA, USA: Edward Elgar Publishing.

McGuire, M., \& Agranoff, R. (2011). The limitations of public management networks. Public Administration, 89(2), 265-284.

McKinney, M., \& Johnson, S. (2009). Working across Boundaries: People, Nature and Regions. Cambridge: Lincoln Institute of Land Policy.

Milward, H.B., \& Provan, K.G. (2006). A Manager's Guide to Choosing and Using Collaborative Networks. Washington, DC: IBM Center for the Business of Government.

O'Leary, R., Gerard, C., \& Bingham, L.B. (2006). Introduction to the symposium on collaborative public management. Public Administration Review, 66, 6-9.

O'Leary, R., \& Bingham, L.B. (Eds.) (2009). The Collaborative Public Manager: New Ideas for the Twenty-First Century. Washington, DC: Georgetown University Press.

O'Leary, R., \& Vij, N. (2012). Collaborative public management: Where have we been and where are we going? American Review of Public Administration, 42(5), 507-522.

Osborne, S.P. (Ed.) (2010). The New Public Governance? Emerging Perspectives on the Theory and Practice of Public Governance. London: Routledge.

O'Toole, L.J. (1995). Rational choice and policy implementation: Implications for interorganizational network management. American Review of Public Administration, 25(1), 43-57.

O'Toole, Jr., L.J. (1997). Treating networks seriously: Practical and research-based agendas in public administration. Public Administration Review, 57(1), 45-52.

Provan, K.G., \& Kenis, P. (2007). Modes of network governance: Structure, management, and effectiveness. Journal of Public Administration Research and Theory, 18(2), 229-252. 
Putnam, R. (2000) Bowling Alone: The Collapse and Revival of American Community. New York: Simon \& Schuster.

Rhodes, R.A.W. (1997). Understanding Governance: Policy Networks, Governance, Reflexivity and Accountability. Maidenhead: Open University Press.

Scott, T.A., \& Thomas, C.W. (2017). Unpacking the collaborative toolbox: Why and when do public managers choose collaborative governance strategies? Policy Studies Journal, 45(1), 191-214.

Simo, G., \& Bies, A. (2007). The role of nonprofits in disaster response: An expanded model of cross-sector collaboration. Public Administration Review, 16(1), 125-142.

Sørensen, E., \& Torfing, J. (Eds) (2007). Theories of Democratic Network Governance. Basingstoke: Palgrave Macmillan.

Sørensen, E., \& Torfing, J. (2009). Making governance networks effective and democratic through metagovernance. Public Administration, 87(2), 234-258.

Teisman, G., \& Klijn, E-H. (2008). Complexity theory and public management. Public Management Review, 10(3), 287-297. doi: 10.1080/14719030802002451

Teisman, G., van Buuren, A., \& Gerrits, L. (Eds.) (2009). Managing Complex Governance Systems: Dynamics, Self-organization and Coevolution in Public Investments. New York; London: Routledge.

Weber, J. (2005). Introduction to chaos, complexity, uncertainty and public administration: A symposium. Public Administration Quarterly, 29(3/4), 262-267. Retrieved October 22, 2020, from http:// www.jstor.org/stable/41288235 